\title{
0-169 好酸球性副鼻腔炎に対するデュピルマブの使用経験
}

○小町太郎 ${ }^{11} 、$ 細矢 慶 ${ }^{2)}$ 、吉野綾穂 ${ }^{3)} 、$ 久家純子 ${ }^{1)}$ 、大久保公裕 ${ }^{3}$

日本医科大学千葉北総病院 耳鼻咽㑨科 ${ }^{11}$ 日本医科大学多摩永山病院 耳鼻咽喉科 ${ }^{2}$ 、

日本医科大学付属病院 耳鼻咽喉・頭頸部外科 ${ }^{32}$

好酸球性副鼻腔炎は難治性・易再発性であり、内視鏡下副鼻腔手術など既存の治療を行っても鼻茸や鼻閉、嗅覚障害の再 発を来しやすい。QOLが著しく低下した場合には、経口ステロイドを投与せざるを得ないことが多いが、経口ステロイド の反復・長期投与は、副腎不全、糖尿病、骨粗鬆症、消化管潰瘍など副作用の出現が懸念される。近年、各種抗体製郕によ る副鼻腔炎に対する治療報告がなされてきているが、2020年 3 月より鼻咠を伴う副鼻腔炎に対して、抗ヒト IL-4/13 受容体 モノクローナル抗体デュピルマブ（デュピクセント）が本邦で保険適応になり、新たな治療選択肢として注目されている。 この適正使用によって、経口ステロイドの使用量の減少抄よび副作用発現のリスク軽減も期待される。当科でも、難病指定 を受けている好酸球性副鼻腔炎（中等症、重症）の術後再発に対してデュピルマブを投与することで、鼻症状、鼻茸、 T\&T オルファクトメトリーなどの改善が得られ、経口ステロイドの使用量減少に寄与できているため、詳細を報告する。

\section{0-170 好酸球性副鼻腔炎の術後に好酸球性多発血管炎性肉芽腫症を発症した例の検討}

○森下裕之、小林正佳、竹内万彦

三重大学大学院 医学系研究科 耳鼻咽喉・頭頸部外科

【目的】好酸球性多発血管炎性肉芽腫症（EGPA）は気管支喘息やアレルギー性鼻炎が先行し、血中好酸球増多を伴う血 管炎症状を来す症候群であり、発症機序は不明である。今回は発症予測のための臨床的因子の有無を検討した。

【方法】2014年 4 月から2019年 3 月の 5 年間に好酸球性副鼻腔炎に対して手術を施行した症例を対象に、末梢血好酸球\% と、気管支喘息、NSAIDs 不耐症、アレルギー性鼻炎の合併の有無、術前術後の鼻咠スコア、副鼻腔 CT スコア、嗅覚機能 を検討した。

【結果】対象84例中 3 例に EGPA の発症を認めた。EGPA群の未梢血好酸球\%は平均21\%で、非 EGPA群の 9 \%よりも高 值であり $(p<0.01) 、 \mathrm{CT}$ スコアの改善度は EGPA 群で不良であった $(p<0.01)$ 。た、 EGPA群は全例術前より気管支喘 息とアレルギー性鼻炎を合併し、好酸球性副鼻腔炎の重症群であった。

【結語】好酸球性副鼻腔炎の術前に末梢血好酸球増多やアレルギー疾患の合併を認める症例や術後もCT の改善がそしい 症例では、EGPA の発症に注意を要する。

\section{0-171＼cjkstart好酸球性副鼻腔炎術後における内視鏡所見の長期経過}

○秋山貢佐、寒川 泰、星川広史

香川大学 医学部 耳鼻咽喉科・頭頸部外科

好酸球性副鼻腔炎（ECRS）の術後コントロールの指標としては症状の重症度評価以外に内視鏡による客観的評価も重要 である。今回われわれは都築らが報告したEスコアを用いて術後の長期経過を検討した。方法：両側 ESS4 型を行った ECRS 121 例で 1 年以上経過観察が可能であった 80 例を対象とし、術後 $3 、 6$ カ月、 1 年〜 5 年時点での Eスコアを記録動 画からスコアリングした。全身性ステロイドの持続投与、再手術、生物学的製剂の使用が行われた症例はその時点で観察期

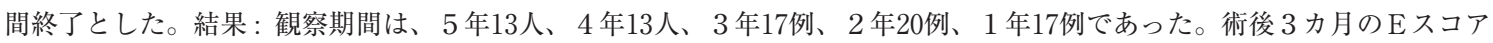

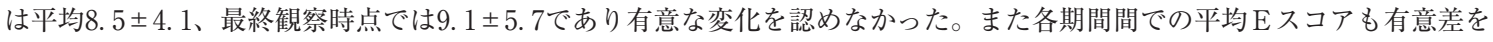
認めなかった。粘膜病変の不良例が $21 / 80$ 例 $(26 \%)$ あり、3 月月時点でのEスコア 12 点以上が長期経過不良を反映すると 考えられた。今回の検討から術後早期の粘膜コントロール状態からその後の長期経過を推測し得る可能性が示唆された。

\section{0-172＼cjkstart好酸球性副鼻腔炎手術症例におけるアレルギー性鼻炎合併についての検討}

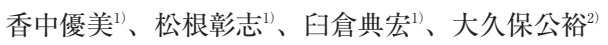

日本医科大学武蔵小杉病院 耳鼻咽喉科 ${ }^{1)}$ 日本医科大学付属病院 耳鼻咽咥科 ${ }^{2}$

従来の慢性副鼻腔炎が炎症の主体が好中球であったのに対し、近年問題になっている難治性の好酸球性副鼻腔炎は副鼻腔 粘膜、鼻茸への高度な好酸球浸潤を特徵とする疾患で、その病態は「2 型炎症」と言われている。これは、Th2 型（I 型ア レルギー）反応と ILC2（自然免疫）反応の両面を有することを意味する。一方で、好酸球性副鼻腔炎（2型炎症）に打け るTh2 型疾患の花粉症・アレルギー性鼻炎の合併の実態については未詳の点が多い。そこで今回、2018年 1 月から2020年 12 月までの 3 年間に、当科で手術加療を行った好酸球性副鼻腔炎抢よび非好酸球性副鼻腔炎症例に打ける花粉症・アレルギ 一性鼻炎の合併について比較検討するとともに、さらに好酸球性副鼻腔炎の重症度と血清総 IgE 值・血清特異的 $\operatorname{IgE}$ 抗体、 末梢血好酸球（\%) などのバイオマーカーとの関連を検討した。その結果、興味深い結果が得られたので、文献的考察を加 えて報告する。 


\section{0-173ＪESREC スコア重症度別の内視鏡下副鼻腔手術術後の予後調査について}

○哚田靖人、坂下雅文、菅野真史、加藤幸宣、木村幸弘、木戸口正典、吉田加奈子、斎藤杏子、宮本大輔、

意元義政、高林哲司、藤枝重治

福井大学病院 医学部 耳鼻咽㑨科頭頸部外科

【背景】慢性副鼻腔炎に対する治療には鼻処置、薬物治療があり、保存的治療に抵抗するものは手術療法の適応となる。 慢性副鼻腔炎に対する内視鏡下副鼻腔手術は標準術式が普及し、良好な成績を収めている。しかし、好酸球性副鼻腔炎では 内視鏡下副鼻腔手術を行っても再発率が高く、JESREC スダディ（後ろ向き観察研究）では、重症なほど術後再発率が高い ことが示された。【目的】JESREC スコアによる重症度の群分けを行い、それらの予後について前向きに検討する。【方法】 JESREC スコアにより非好酸球性副鼻腔炎と軽症好酸球性副鼻腔炎、中等症好酸球性副鼻腔炎、重症好酸球性副鼻腔炎に分 け、前向きの観察研究を行った。福井大学において、2015年 1 月 1 日以降に慢性副鼻腔炎に対する内視鏡下副鼻腔手術を施 行した141例について、術前と術後 6 カ月における症状（鼻閉感、粘稠な鼻汁、頭痛、嗅覚の低下についての visual analog scale)、鼻内所見（ポリープスコア）、内服（内服ステロイド薬、鼻噴霧型ステロイド、そのほか内服）、重症度、再発に関 して比較し、報告する。

\section{0-174 重症好酸球性副鼻腔炎に対する生物学的製剤の治療適応}

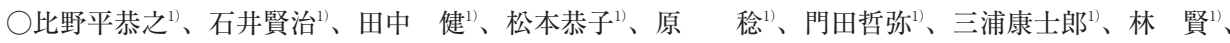

森 智昭2 、渡邊 荘 ${ }^{3} 、$ 本岡大心 ${ }^{11}$ 、神尾友信 ${ }^{1}$

神尾記念病院 耳鼻咽喉科 ${ }^{12}$ 、昭和大学江東豊洲病院 耳鼻咽喉科 ${ }^{22}$ 、

国立国際医療研究センター国府台病院 耳鼻咽喉科 ${ }^{3)}$

好酸球性副鼻腔炎は難治性であり、JESREC Studyで重症に分類される喘息やアスピリン不耐症合併例は内視鏡下鼻内副 鼻腔手術（ESS）を行っても鼻茸の再発が多い。原因として前頭洞病変が多く、このため拡大前頭洞手術を行い再発に対処 してきた。しかし拡大手術を行ってもな扮鼻茸の再発を繰り返す症例は存在する。副鼻腔術後再発例に対して2020年より IL-4/13 を標的とした生物学的製剤の適応が可能となった。当院における治療適応について報告する。

2017年 9 月以降に ESS を行い、重症好酸球性副鼻腔炎と診断して 1 年以上経過観察を行っている54例を検討対象とし た。ESS は Draf IIb を原則とし、他施設などで初回手術を受けた16例の再手術例では10例に Draf III を行った。7例では術 後鼻茸のコントロールが不良であり生物学的製剤の投与適応とした。投与後の経過は良好であった。

ESS に拡大前頭洞手術を加えることで重症好酸球性副鼻腔炎例における術後経過は良好であった。拡大手術を行ってもな お鼻茸の再発を繰り返す例では生物学的製剤投与を考慮する必要がある。

\section{0-175 好酸球性副鼻腔炎診療における現在の問題点の検討}

○松山敏之、川崎裕正、清水龍吾、井田翔太、御任一光、多田紘恵、高橋秀行、近松一朗 群馬大学 耳鼻咽喉科頭頸部外科

好酸球性副鼻腔炎は2014年に診断基準が確立し、2015年には指定難病として登録された。2020年には生物学的製剤による 新規治療も始まり、病態解明や診断基準、治療法確立が日進月歩で発展している。疾患の認知とともに、診断基準を満たす 患者数は増え、JESREC study での患者数約 20,000 人より増えている印象を受ける。現在の難病申請は、JESREC study の診 断基準に基づき申請更新を行い、重症度制限はなく、耳鼻咽喉科以外の難病指定医でも申請更新が行える。一方、合併する 気管支喘息に対して、生物学的製剤が使用されることにより血中および組織中好酸球数が低值になり、診断、指定難病の申 請ができないケースもみられ、重症患者ほど、難病指定ができない事態も生じている。ほかにも、生物学的製剤の投与間隔 基準や中止基準がないこと、ほかの生物学的製剤との併用投与の可否等、その問題点は多岐にわたる。今回、われわれは当 科の好酸球性副鼻胿炎患者を対象に、診断、治療、難病申請に関する問題点の検討を行ったので報告する。

\section{0-176 側頭骨に生じた Giant Cell Reparative Granuloma の 1 症例}

○麻植章弘、結束＼cjkstart寿、高橋昌寛、志村英二、山本＼cjkstart裕、小島博己

東京慈恵会医科大学附属病院 医学部 耳鼻咽喉・頭頸部外科

Giant Cell Reparative Granuloma（GCRG；巨細胞修復性肉芽腫）は上顎骨や下顎骨に生じることが多く、側頭骨に発生 した報告は少ない。病因は不明であるが、炎症や外傷との関連が考えられている。その治療は腫瘍の全摘出であり、掻爬な どの不完全な外科的治療であった場合の再発率は高い。今回、われわれは側頭骨を原発とした GCRGに対し手術を行い、 完全切除を得た症例を経験したので若干の文献的考察を含め報告する。症例は47歳女性。頑固な頭痛と左耳痛を主訴に当科 紹介受診された。画像検查では左側頭骨に浸潤性腫瘤性病変を認め、外耳道、上鼓室、中頭蓋底、顎関節窩への進展を認め た。外耳道からの腫瘤生検により GCRG の診断となった。側頭開頭を併施した拡大外側側頭骨切除を施行し、顎関節㧍よ び中頭蓋底硬膜の一部を合併切除することで病変を一塊に摘出した。顔面神経は温存した。硬膜欠損部位は側頭筋膜で再建 し、顎関節・頬骨切除部位は肋骨付き前鋸筋皮弁で再建を行った。術後は一時的な顔面神経麻痺は認めたものの経過は良好 であり、術後18日で軽快退院した。 